\title{
PENGARUH KOMPENSASI DAN MOTIVASI TERHADAP KINERJA KARYWAN PT ASIAN TEC INDONESIA JAKARTA UTARA
}

\author{
Muhammad Firizki Arief 1) \\ 1) Mahasiswa Program Studi Manajemen FE UNKRIS \\ Nuridin ${ }^{2)}$ \\ 2) Dosen Program Studi Manajemen FE UNKRIS \\ Diajeng Reztrianti ${ }^{3)}$ \\ 3) Dosen Program Studi Manajemen FE UNKRIS \\ Alamat: Kampus UNKRIS, Jatiwaringin Jakarta Timur \\ Email: luckydwi170465@gmail.com
}

\begin{abstract}
To determine the effect of compensation and motivation on employee performance PT Asian Tec Indonesia North Jakarta. This research is included in the category of causal associative research using a quantitative approach. The research was conducted by distributing questionnaires to 30 respondents, all of whom were employees of PT Asian Tec Indonesia, North Jakarta, while the research method used partially and simultaneous linear regression analysis. The hypothesis states that partially compensation and motivation have a positive effect on employee performance. The hypothesis which states that compensation and motivation simultaneous have an effect on employee performance.
\end{abstract}

Keywords: Compensation, motivation and employee performance

\section{PENDAHULUAN}

Di era globalisasi sekarang ini dalam dunia bisnis perusahaan dituntut untuk lebih meningkatkan kinerja karyawan agar dapat mengembangkan perusahaan. Keberhasilan suatu perusahaan dipengaruhi oleh beberapa faktor, salah satunya faktor penting adalah sumber daya manusia, karena sumber daya manusia adalah perilaku dari seluruh tingkat perencanaan sampai dengan evaluasi yang mampu memanfaatkan sumber daya lainnya yang dimiliki oleh sebuah organisasi atau perusahaan. Keberadaan sumber daya manusia pada suatu perusahaan memegang peranan yang sangat penting. Tenaga kerja yang memiliki kemampuan besar untuk menjalankan kegiatan perusahaan dimana kemampuan setiap sumber daya manusia yang ada dalam perusahaan harus dapat dimanfaatkan dengan sebaiksebaiknya sehingga mampu mendapatkan output optimal.

Tercapainya suatu tujuan perusahaan tidak hanya tergantung pada peralatan modern saja, sarana dan prasarana yang lengkap, tetapi justru lebih bergantung pada manusia yang melaksanakan pekerjaan tersebut. Keberhasilan suatu perusahaan sangat dipengaruhi oleh kinerja setiap individunya. Perusahaan akan selalu berusaha untuk meningkatkan kinerja karyawan dengan harapan tujuan perusahaan akan tercapai. Untuk dapat meningkatkan kinerja setiap karyawan, perusahaan menempuh berbagai cara dengan pemberian kompensasi yang memuaskan, menciptakan motivasi yang harmonis. Melalui langkahlangkah tersebut, karyawan diharapkan akan lebih memaksimalkan tanggungjawab dalam melaksanakan pekerjaannya.

Pemberian kompensasi dan motivasi adalah hak para karyawan atau kewajiban dari pihak perusahaan untuk mendukung kontribusi para pekerja dalam rangka mencapai tujuan 
yang telah ditentukan. Pemberian kompensasi yang memadai sangat dibutuhkan oleh karyawan. Pemberian kompensasi yang baik kepada karyawan akan memberikan dampak positif pada sebuah perusahaan, diantaranya: (1). Memacu karyawan untuk berprestasi dan bekerja lebih giat. (2). Perusahaan mendapat pekerja yang berkualitas baik. (3). Memudahkan proses administrasi dan aspek hukum. (4). Menjadi daya pikat bagi pencari kerja yang berkualitas. (5). Perusahaan memiliki kelebihan tersendiri dibanding kompetitor. Kompensasi menurut Umar (2007), adalah "segala sesuatu yang diterima oleh karyawan, baik itu berupa gaji, upah, insentif, bonus, premi, pengobatan, asuransi dan lain-lain, dan sejenisnya yang di bayar langsung perusahaan".

Dengan diberikannya kompensasi yang layak kepada karyawan, tentunya harapan dari perusahaan adalah dapat meningkatkan kinerja para karyawan dan ini akan tercapainya tujuan dari perusahaan yaitu mendapatkan keuntungan.

Faktor lain yang dapat meningkatkan kinerja karyawan adalah adanya pemberian motivasi pada karyawan oleh pimpinan perusahaan, bukanlah suatu kebetulan saja, pemberian motivasi akan dapat dicapai jika didahului dengan perbuatan yang telah melaksanakan tugas yang dibebankan. Setiap karyawan dapat lebih termotivasi untuk mengerjakan tanggungjawab atas pekerjaan mereka jika perusahaan mengerti dan memerhatikan betul akan kebutuhan setiap karyawan yang pada dasarnya merupakan mereka bekerja untuk mendapatkan uang dalam hal ini berbentuk gaji.

Motivasi merupakan suatu perubahan yang terjadi pada diri seseorang yang muncul adanya gejala perasaan, kejiwaan dan emosi sehingga mendorong individu untuk melakukan atau bertindak sesuatu yang disebabkan karena kebutuhan, keinginan dan tujuan.

Perusahaan harus memperhatikan faktor motivasi. Karyawan dapat melaksanakan tugasnya secara maksimum dengan adanya dorongan dan dukungan dari pimpinan dengan memperhatikan kesejahteraan mereka. Motivasi mendorong perilaku atau keinginan seseorang untuk melakukan suatu kegiatan yang dinyatakan dalam bentuk usaha yang keras atau lemah. Pemahaman terhadap motivasi karyawan akan angat penting kaitannya dengan pencapaian tujuan, yaitu produktivitas dan efesiensi.

Terpenuhinya kompensasi dan pemberian motivasi yang baik tentu saja akan meningkatkan produktivitas serta kinerja para karyawan.

Kinerja karyawan merupakan suatu hal yang sangat penting dalam usaha perusahaan untuk mencapai tujuannya. Oleh karena itu, salah satu cara terbaik untuk meningkatkan kapasitas kinerja karyawan adalah dengan menghubungkan kompensasi dengan perkembangan karyawan. Jika program kompensasi dirasakan adil dan kompetitif oleh karyawan, maka perusahaan akan lebih mudah untuk menarik karyawan yang potensial, mempertahankannya dan memotivasi karyawan agar lebih meningkatkan kinerjanya, sehingga produktivitas meningkat dan perusahaan mampu menghasilkan produk dengan harga yang kompetitif. Pada akhirnya, perusahaan bukan hanya unggul dalam persaingan, namun juga mampu mempertahankan kelangsungan hidupnya, bahkan mampu meningkatkan profitabilitas dan mengembangkan usahanya.

Sekarang ini, perkembangan teknologi komunikasi dan informasi yang begitu pesatnya semakin ketat sehingga tingkat persaingan bisnis semakin sangat kompetiti mengakibatkan perusahaan dihadapkan pada tantangan untuk dapat mempertahankan kelangsungan hidup.

Salah satunya PT Asian Tec Indonesia adalah anak perusahaan dari Asian Tec Limited yang berpusat di kawasan Hongkong dan Guang Zhou, Cina. Sebagai perusahaan induk Asian Tec Limited, keahlian di bidang manufaktur dan perawatan Water Treatment Industrial di wilayah China dan Asia Tenggara. 
Asian Tec Indonesia didirikan di Jakarta, Indonesia sejak tahun 2006 oleh tenaga berpengalaman kami yang ahli di bidang Pembangkit Listrik Tenaga Uap dan Instalasi Pengolahan Air sejak tahun 1990-an. Asian Tec Indonesia berlokasi di Kelapa Gading, Jakarta Utara, Indonesia. Mall Artha /Graha Rekso Rukan Gading Kirana Barat IX Blok D6 No. 39 Kelapa Gading Barat Kota Jakarta Utara, DKI Jakarta.

Dalam kondisi sekarang ini kinerja karyawan mulai menurun, target yang ditetapkan oleh perusahaan tidak sesuai, belum lagi masalah gaji dan bonus juga menjadi salah satu penyebab menurunnya kinerja karyawan, banyak karyawan yang beranggapan bahwa besarnya tanggungjawab pekerjaan tidak sesuai dengan penghasilan yang didapat. Disamping itu factor lain yang menyebabkan menurunnya kinerja karyawan PT Asian Tec Indonesia yaitu masalah motivasi kerja, banyak karyawan sudah mulai jenuh atas pekerjaannya, hal ini terjadi karena kurangnya perhatian dan motivasi yang diberikan oleh pimpinan perusahaan.

Tujuan penelitian ini adalah untuk mengetahui pengaruh kompensasi dan motivasi terhadap kinerja karyawan PT Asian Tec Indonesia Jakarta Utara.

\section{LANDASAN TEORI}

\section{Kompensasi}

Menurut Hasibuan (2017) Kompensasi adalah "semua pendapatan yang berbentuk uang, barang langsung atau tidak langsung yang diterima karyawan sebagai immbalan atas jasa yang diberikan kepada perusahaan". Menurut Handoko (2014) Kompensasi adalah "segala sesuatu yang diterima para karyawan sebagai balas jasa untuk kerja mereka". Program-program kompensasi juga penting bagi perusahaan, karena mencermintakan upaya organisasi untuk mempertahankan sumber daya manusia. Sedangkan menururt Wibowo (2016) Kompensasi adalah "jumlah paket yang ditawarkan organisasi kepada pekerja sebagai imbalan atas penggunaan tenaga kerjanya”. Menurut Marwansyah (2016) Kompensasi adalah "penghargaan atau imbalan langsung maupun tidak langsung, finansial maupun non finansial, yang adil dan layak kepada karyawan, sebagai balasan atau kontribusi/jasanya terhadap pencapaian tujuan perusahaan". Menurut Sunyoto (2012) kompensasi adalah "konsep yang lebih luas, kompensasi adalah semua bentuk kembalian atau imbalan (return) finansial, jasa-jasa berwujud dan tujuan-tujuan yang diperoleh sebagai dari sebuah hubungan kepegawaian".

Berdasarkan definisi tersebut, penulis menyimpulkan bahwa kompensasi merupakan unsur biaya pengeluaran bagi perusahaan yang dikeluarkan sebagai balas jasa pada karyawan atas pengorbanan sumberdaya (waktu, tenaga, dan pikiran) serta kompetensi (pengetahuan, keahlian, dan kemampuan) yang telah mereka curahkan selama periode waktu tertentu sebagai sumbangan pada pencapaian tujuan organisasi dan diterimakan karyawan sebagai pendapatan yang merupakan bagian dari hubungan kepegawaian yang dikemas dalam suatu sistem imbalan jasa.

Menurut Managkunegara (2017) ada dua bentuk kompensasi yaitu bentuk kompensasi langsung yang merupakan upah dan gaji, bentuk kompensasi yang tak langsung yang merupakan pelayanan dan keuntungan. 1). "Upah dan Gaji (Kompensasi dalam bentuk langsung); Upah adalah pembayaran berupa uang untuk pelayanan kerja atau uang yang biasanya di bayarkan kepada karyawan secara per jam, per hari, dan per setengah hari. Sedangkan gaji merupakan uang yang di bayarkan kepada karyawan atas jasa pelayanannya yang yang diberikan secara bulanan. 2). Keuntungan dan Pelayanan; Keuntungan adalah nilai keuangan (moneter) langsung untuk karyawan yang secara cepat dapat dilakukan. Sedangkan pelayanan adalah nilai keuangan (moneter) langsung untuk karyawan yang tidak 
dapat secara mudah ditentukan. Program benefit (keuntungan) bertujuan untuk memperkecil turnover, meningkatkan modal kerja, dan meningkatkan keamanan. Adapun kriteria keuntungan adalah biaya, kemampuan membayar, kebutuhan, kekuatan kerja, tanggung jawab sosial, reaksi kekuatan kerja, dan relasi umum. Sedangkan program pelayanan adalah laporan tahunan untuk karyawan, adanya tim olah raga, kamar tamu karyawan, kafetaria karyawan, surat kabar perusahaan, toko perusahaan, discount (potongan harga), produk perusahaan, ada program rekreasi atau darmawisata".

Menurut Hasibuan, (2017) faktor-faktor yang mempengaruhi besarnya kompensasi, antara lain yaitu: 1). "Penawaran dan permintaan tenaga kerja. 2). Kemampuan yang dan kesediaan perusahaan. 3). Serikat buruh atau organisasi karyawan. 4). Produktivitas kerja karyawan. 5). Pemerintah dengan undang-undang dan keppresnya. 6). Biaya hidup atau cost of living. 7). Posisi jabatan karyawan. 8). Pendidikan dan pengalaman karyawan. 9). Kondisi perekonomian nasonal. 10). Jenis dan sifat pekerjaan".

Indikator dalam pemberian kompensasi untuk karyawan tentu berbeda-beda. Menurut Simamora (2010) mengemukakan secara umum indikator kompensasi, yaitu: 1). "Upah dan gaji, Upah adalah basis bayaran yang seringkali digunakan bagi para pekerja produksi dan pemeliharaan. Upah pada umumnya berhubungan dengan tarif gaji per jam dan gaji biasanya berlaku untuk tarif bayaran tahunan, bulanan atau mingguan. 2). Insentif, Pengertian Insentif adalah tambahan kompensasi di atas atau di luar gaji atau upah yang diberikan oleh perusahaan. 3). Tunjangan, Pengertian Tunjangan adalah asuransi kesehatan dan jiwa, program pensiun, liburan yang ditanggung perusahaan, dan tunjangan lainnya yang berkaitan dengan hubungan kepegawaian. 4). Fasilitas, Pengertian Fasilitas adalah pada umumnya berhubungan dengan kenikmatan seperti mobil perusahaan, akses ke pesawat perusahaan, tempat parkir khusus dan kenikmatan yang diperoleh karyawan”.

\section{Motivasi}

Menurut Uno (2011), definisi motivasi diartikan "sebagai bentuk dorongan secara internal dan eksternal dari dalam diri seseorang yang diindikasikan dengan adanya; hasrat dan minat; dorongan dan kebutuhan; harapan dan cita-cita; penghargaan dan penghormatan". Menurut Simamora, (2010) "motivasi merupakan sebuah fungsi yang berasal dari bentuk pengharapan individu bahwa upaya tertentu akan menghasilkan tingkat kinerja yang pada gilirannya akan membuahkan imbalan atau hasil yang dikehendaki". Selanjutnya Terry (2005) menyatakan bahwa "motivasi merupakan sebuah keinginan yang terdapat pada diri seseorang yang merangsangnya untuk melakukan berbagai tindakan". Menurut Flippo (2013) mengatakan bahwa motivasi adalah "suatu bentuk keahlian dalam mengarahkan seorang karyawan atau sebuah organisasi untuk mencapai keberhasilan dalam bekerja sehingga tujuan dari organisasi dapat tercapai".

Berdasarkan pengertian tersebut dapat disimpulkan bahwa peranan motivasi sangat penting dalam organisasi atau perusahaan yang dapat mempengaruhi karyawan dalam bekerja, dan membuat karyawan bersemangat untuk bekerja.

Menurut Mangkunegara (2017) terdapat 5 teori motivasi yang sering digunakan dan akan dijelaskan dengan jelas dibawah ini. 1). "Teori Hierarki Maslow; Teori Hierarki dikemukakan oleh Abraham Maslow, seorang psikologi di tahun 1943. Dalam teori ini dikatakan bahwa tingkatan kebutuhan hidup manusia didasarkan pada 5 jenis, mulai dari kebutuhan mendasar hingga kebutuhan yang paling tinggi. Tingkatan hierarki yang dimaksud adalah sebagai berikut: a). Kebutuhan Fisiologis; Kebutuhan hidup manusia yang paling dasar, seperti kebutuhan terhadap makanan, minuman, air, udara, pakaian, tempat tinggal dan kebutuhan untuk bertahan hidup. b). Kebutuhan Keamanan; Kebutuhan hidup manusia untuk memperoleh rasa aman dari kekerasan, baik secara fisik maupun psikis. 
Misalnya, lingkungan tempat tinggal yang bebas polusi, perlindungan keselamatan dari bahaya dan ancaman dalam hidupnya. c). Kebutuhan Sosial; Sesuai dengan sifat manusia sebagai makhluk sosial, yang membutuhkan orang lain dalam menjalankan hidupnya. Kebutuhan ini mengisyaratkan manusia untuk memiliki rasa mencintai dan dicintai. d). Kebutuhan Penghargaan; Kebutuhan yang berkaitan dengan fisiologis, keamanan dan sosial. Kebutuhan itu menjadikan orang tersebut berharap diakui oleh orang lain, memiliki reputasi dan rasa percaya diri serta dihargai oleh orang lain. e). Kebutuhan Aktualisasi diri; Kebutuhan yang paling tinggi dalam hidup manusia menurut Maslow, yaitu kebutuhan manusia untuk dapat memenuhi ambisi pribadinya. 2). Teori ERG Alderfer; Teori ERG Alderfer atau biasa dikenal dengan ERG saja dikemukakan oleh Alderfer yang diambil dari bentuk persamaan $\mathrm{E}=$ Existence yang berarti eksistensi kebutuhan, seperti fisiologis dan materialistis, $\mathrm{R}=$ Relatedness yang menyatakan hubungan dengan pihak lainnya, serta $\mathrm{G}=$ Growth yang diartikan sebagai kebutuhan tumbuh untuk mencapai potensi diri yang maksimal. 3). Teori Kebutuhan McClelland; David McClelland merupakan seorang psikolog yang mengemukakan pendapatnya mengenai teori dalam motivasi yang dibagi kedalam 3 jenis kebutuhan, yaitu kebutuhan prestasi, kebutuhan afiliasi dan kebutuhan akan kekuasaan. 3). Teori Motivasi Hygiene Herzberg; Teori Herzberg sering disebut juga sebagai teori dua faktor yang berbeda, yakni tingkat kepuasan dan ketidakpuasan dalam bekerja atau disebut juga dengan teori $\mathrm{M}-\mathrm{H}$. a). Kepuasan bekerja, yaitu faktor yang berhubungan dengan pengakuan, prestasi, tanggung jawab yang memberikan kepuasan positif bagi karyawan. b). Ketidakpuasan bekerja, yaitu faktor yang berhubungan dengan kondisi lingkungan kerja, hubungan antar individu, keamanan bekerja maupun gaji yang memberikan rasa tidak puas bagi karyawannya. 4). Teori Harapan Vroom; Victor Vroom yang merupakan seorang profesor di Kanada mengungkapkan teori motivasi dalam bukunya "Work and Motivation" yang berbunyi bahwa seseorang akan melakukan suatu tindakan karena mengharapkan hasil atau imbalan. Konsep teori harapan Vroom adalah sebagai berikut: a). Harapan (Expectancy), yaitu tingkat kepercayaan seseorang bahwa suatu usaha akan menghasilkan kinerja tertentu. b). Instrumentally, yaitu tingkat kepercayaan seseorang bahwa suatu kinerja yang dilakukan bisa mendapatkan hasil tertentu. c). Valensi (Valence), yaitu berkaitan dengan nilai positif dan negatif dari hasil yang telah dicapai".

Adapun tujuan pemberian motivasi menurut Hasibuan (2017) antara lain adalah: 1). "Mendorong gairah dan semangat kerja karyawan. 2). Meningkatkan moral dan kepuasan kerja karyawan. 3). Meningkatkan produktifitas kerja karyawan.

Mempertahankan loyalitas dan kestabilan karyawan organisasi. 5). Meningkatkan kesiplinan dan menurunkan tingkat absensi karyawan. 6). Mengefetifkan pengadaan karyawan. 7). Menciptakan suasana dan hubungan kerja yang baik. 8). Meningkatkan kreatifitas dan partisifasi karyawan. 9). Meningkatkan tingkat kesejahteraan karyawan. 10). Mempertinggi rasa tanggung jawab karyawan terhadap tugas-tugasnya.

Meningkatkan efisiensi penggunaan alat-alat dan bahan baku".

Menurut Afandi (2018) menyebutkan beberapa indikator dari motivasi yaitu sebagai berikut: 1). "Balas jasa; Segala sesuatu yang berbentuk barang, jasa, dan uang yang merupakan kompensasi yang diterima karyawan karena jasanya yang dilibatkan pada organisasi. 2). Kondisi kerja; Kondisi atau keadaan lingkungan kerja dari suatu perusahaan yang menjadi tempat bekerja dari para karyawan yang bekerja dalam lingkungan tersebut. Kondisi kerja yang baik yaitu nyaman dan mendukung pekerja untuk dapat menjalankan aktivitasnya dengan baik. 3). Fasilitas kerja; Segala sesuatu yang terdapat dalam organisasi yang ditempati dan dinikmati oleh karyawan, baik dalam hubungan langsung dengan pekerjaan maupun untuk kelancaran pekerjaan. 4). Prestasi kerja; Hasil yang dicapai atau yang diinginkan oleh semua orang dalam bekerja. Untuk 
tiap-tiap orang tidaklah sama ukuranya karena manusia itu satu sama lain berbeda. 5). Pengakuan dari atasan; Pernyataan yang diberikan dari atasan apakah karyawannya sudah menerapkan akan motivasi yang telah diberikan atau tidak. 6 6). Pekerjaan itu sendiri; Karyawan yang mengerjakan pekerjaan dengan sendiri apakah pekerjaannya bisa menjadi motivasi buat karyawan lainnya".

\section{Kinerja}

Menurut Mangkunegara (2017) kinerja merupakan istilah yang berasal dari kata job performance atau actual performance (prestasi kerja atau kinerja sesungguhnya yang dicapai seseorang). Pengertian kinerja adalah "hasil kerja secara kualitas dan kuantitas yang dicapai oleh seorang karyawan dalam melaksanakan tugasnya sesuai dengan tanggung jawab yang diberikan kepadanya". Edison, et al (2016) menjelaskan bahwa "kinerja adalah hasil dari suatu proses yang mengacu dan di ukur selama periode waktu tertentu berdasarkan ketentuan atau kesepakatan yang telah ditetapkan sebelumnya". Selanjutnya Menurut Wibowo (2016) Kinerja adalah "implementasi dari rencana yang telah disusun tersebut. Implementasi kinerja dilakukan oleh sumber daya manusia yang memiliki kemampuan, kompetensi, motivasi, dan kepentingan. Bagaimana organisasi menghargai dan memperlakukan sumber daya manusianya akan memengaruhi sikap dan perilakunya dalam menjalankan kinerja". Sementara menurut Rivai (2014), "kinerja merupakan perilaku nyata yang ditampilkan setiap orang sebagai prestasi kerja yang dihasilkan oleh karyawan sesuai dengan perannya dalam perusahaan".

Dari beberapa pendapat diatas maka dapat diketahui bahwa kinerja merupakan hasil kerja yang dicapai oleh seseorang karyawan sesuai dengan pekerjaan yang diberikan kepadanya dalam waktu tertentu. Kinerja juga merupakan perwuju dan kerja yang dilakukan oleh karyawan yang biasanya digunakan sebagai dasar penilaian terhadap karyawan atau organisasi. Kinerja yang baik merupakan suatu langkah utama untuk menuju tercapainya suatu tujuan organisasi.

Tujuan evaluasi kinerja adalah untuk memperbaiki atau meningkatkan kinerja organisasi melalui peningkatan kinerja dari Sumber Daya Manusia organisasi. Secara lebih spesifik, tujuan evaluasi kerja sebagaimana dikemukakan Sunyoto dalam Mangkunegara (2017) yaitu: 1). "Meningkatkan saling pengertian antara sesama karyawan tentang persyaratan kinerja. 2). Mencatat dan mengakui hasil kerja seorang karyawan, sehingga mereka termotivasi untuk dapat berbuat dengan lebih baik, atau sekurangkurangnya berprestasi yang sama seperti hal nya prestasi yang terdahulu. 3). Memberi peluang kepada karyawan untuk mendiskusikan keinginan dan aspirasinya dalam upaaya meningkatkan kepedulian terhadap karier atau terhadap pekerjaan yang diembannya sekarang. 4). Mendefinisikan atau merumuskan kembali tujuan atau target masa depan, sehingga karyawan termotivasi untuk berpartisipasi sesuai dengan potensinya. 5). Memeriksa rencana pelaksanaan dan pengembangan yang sesuai dengan kebutuhan pelatihan, khususnya dalam rencana pendidikan latihan, dan kemudian menyetujui rencana itu jika tidak ada hal-hal yang perlu diubah".

Menurut Mangkunegara (2017) kegunaan penilaian kinerja karyawan yaitu: "Sebagai dasar dalam pengambilan keputusan yang digunakan dalam menilai suatu prestasi, pemberhentian kerja serta besarnya balas jasa. 2). Untuk mengukur sejauh mana seorang karyawan dapat menyelesaikan pekerjaannya. 3). Sebagai dasar dalam mengevaluasi efektivitas seluruh kegiatan dalam perusahaan. 4). Sebagai dasar untuk mengevaluasi program latihan dan ke efektifan jadwal kerja, metode kerja, struktur organisasi, gaya pengawasan, kondisi kerja dan pengawasan. 5). Sebagai indikator untuk menentukan kebutuhan akan latihan bagi karyawan yang berada di dalam organisasi. 6). 
Sebagai alat untuk meningkatkan motivasi kerja karyawan sehingga dicapai performance yang baik. 7). Sebagai alat untuk melihat kekurangan atau kelemahan dan meningkatkan kemampuan karyawan selanjutnya. 8). Sebagai kriteria menentukan, seleksi dan penempatan karyawan. 9). Sebagai alat untuk memperbaiki atau mengembangkan kecakapan karyawan. 10). Sebagai dasar untuk memperbaiki atau mengembangkan uraian tugas (job description)".

Menurut Afandi (2018) indikator-indikator kinerja karyawan adalah sebagai berikut : 1). "Kuantitas hasil kerja; Segala macam bentuk satuan ukuran yang berhubungan dengan jumlah hasil kerja yang bisa dinyatakan dalam ukuran angka atau padanan angka lainnya. 2). Kualitas hasil kerja; Segala macam bentuk satuan ukuran yang berhubungan dengan kualitas atau mutu hasil kerja yang dapat dinyatakan dalam ukuran angka atau padanan angka lainnya. 3). Efesiensi dalam melaksanakan tugas; Berbagai sumber daya secara bijaksana dan dengan cara yang hemat biaya. 4 4). Disiplin kerja; Taat kepada hokum dan peraturan yang berlaku. 5). Inisiatif; Kemampuan untuk memutuskan dan melakukan sesuatu yang benar tanpa harus diberi tahu, mampu menemukan apa yang seharusnya dikerjakan terhadap sesuatu yang ada di sekitar, berusaha untuk terus bergerak untuk melakukan beberapa hal walau keadaan terasa semakin sulit. 6). Ketelitian; Tingkat kesesuaian hasil pengukuran kerja apakah kerja itu udah mencapai tujuan apa belum. 7). Kepemimpinan; Proses mempengaruhi atau memberi contoh oleh pemimpin kepada pengikutnya dalam upaya mencapai tujuan organisasi. 8). Kejujuran; Salah satu sifat manusia yang cukup sulit untuk diterapkan. 9). Kreativitas; Proses mental yang melibatkan pemunculan gagasan atau yang melibatkan pemunculan gagasan".

\section{METODE PENELITIAN}

Penelitian ini termasuk dalam kategori penelitian asosiatif kausal dengan menggunakan pendekatan kuantitatif. Penelitian dilakukan dengan menyebar kuesioner pada responden sebanyak 30 orang yang seluruhnya adalah karyawan PT Asian Tec Indonesia Jakarta Utara, sedangkan metode penelitian dengan menggunakan analisis regresi linear sederhana dan berganda.

\section{HASIL PENELITIAN DAN PEMBAHASAN}

\section{Hasil Penelitian}

\section{Uji instrumen data}

Berdasarkan uraian tersebut, untuk dapat menentukan variabel kompensasi dan motivasi dapat dijadikan pengukur terhadap kinerja karyawan PT Asian Tec Indonesia Jakarta Utara. Namun sebelumnya data diolah terlebih dahulu dan dilakukan pengujian terhadap variabel yang digunakan yaitu kompensasi, motivasi dan kinerja untuk mengetahui data tersebut akurat dan dapat dipercaya.

\section{Uji validitas}

Pengujian validitas ini dilakukan untuk menguji apakah tiap butir pernyataan telah mewakili indikator yang akan diteliti, persyaratan minimum untuk dapat dikatakan valid adalah $\mathrm{r}=0,30$. Jadi, apabila korelasi antara butir-butir item pernyataan dengan skor total kurang dari 0,30, maka butiran dalam instrumen tersebut dapat dikatakan tidak valid. Uji validitas dilakukan dengan melihat korelasi antara skor masing-masing item pernyataan dengan skor total. (Sugiyono, 2017). 
Dari perhitungan koefisien korelasi skor tiap butir pernyataan dari 30 responden tentang instrumen kompensasi, dengan jumlah 8 butir pernyataan; instrumen motivasi 8 butir pernyataan dan instrumen kinerja karyawan 9 butir pernyataan dengan total skor setiap responden diperoleh hasil $\mathrm{r}$ hitung lebih besar dari $\mathrm{r}$ kritis $=0,30$, maka seluruh item pernyataan didapatkan menunjukkan hasil yang valid.

\section{Uji reliabilitas}

Pengujian reliabilitas ini dilakukan untuk menguji seberapa jauh hasil pengukuran yang dapat diandalkan secara konsisten. Pada tabel hasil pengujian reliabilitas berikut, diketahui bahwa semua variabel mempunyai alpha di atas 0,6 yang berarti bahwa semua variabel dalam penelitian ini dapat diandalkan.

Tabel 1: Hasil Uji Reliabilitas

\begin{tabular}{|c|c|c|c|}
\hline Variabel & $\begin{array}{c}\text { Cronbach } \\
\text { Alpha }\end{array}$ & $\begin{array}{l}\text { Nilai kritis } \\
(\alpha)=5 \%\end{array}$ & Keterangan \\
\hline Kompensasi & 0.623 & 0.600 & Reliabel \\
\hline Motivasi & 0.615 & 0.600 & Reliabel \\
\hline Kinerja Karyawan & 0.622 & 0.600 & Reliabel \\
\hline
\end{tabular}

Sumber: Data Primer, diolah tahun 2021

Berdasarkan angka-angka reliabilitas cronbach alpha tersebut tampak bahwa seluruh pernyataan yang ada membentuk ukuran yang reliabel kompensasi, motivasi, dan kinerja karyawan membentuk ukuran yang reliabel dari masing-masing variabel.

\section{Analisis regresi linear sederhana}

Tabel 2: Pengaruh Kompensasi Terhadap Kinerja Karyawan

\begin{tabular}{|c|c|c|c|c|c|c|}
\hline \multirow[b]{2}{*}{ Variabel } & \multicolumn{6}{|c|}{ Parameter } \\
\hline & $\mathbf{R}$ & $\begin{array}{c}\mathbf{R} \\
\text { Square }\end{array}$ & Konstanta & $\begin{array}{c}\text { Koefisien } \\
\text { Regresi }\end{array}$ & Sig & $\alpha$ \\
\hline Kompensasi & 0,806 & 0,649 & 14,161 & 0,778 & 0,000 & 0.01 \\
\hline \multicolumn{7}{|c|}{ Pengujian Signifikan } \\
\hline \multicolumn{7}{|c|}{$\mathrm{t}$ hitung $>\mathrm{t}$ tabel $=7,200>2,048$} \\
\hline
\end{tabular}

Berdasarkan Tabel 2, nilai koefisien determinasi $\left(\mathrm{R}^{2}\right)$ sebesar 0.649, artinya kompensasi memberikan kontribusi sebesar 64,9\% terhadap kinerja karyawan PT Asian Tec Indonesia, sedangkan sisanya sebesar 35,1\% disumbangkan faktor lain.

Persamaan regresi : $\mathrm{Y}=14,161+0,778\left(\mathrm{X}_{1}\right)$

Kompensasi berpengaruh positif dan signifikan pada tingkat nyata 99\% terhadap kinerja karyawan PT Asian Tec Indonesia. Koefisien kompensasi sebesar 0,778, artinya jika ada peningkatan kompensasi, maka kinerja karyawan PT Asian Tec Indonesia akan meningkat.

Tabel 3: Pengaruh Motivasi Terhadap Kinerja Karyawan

\begin{tabular}{c} 
Variabel Parameter \\
\hline is licensed under a Creative Commons Attribution-Nomercial-ShareAlike 4.0 International License.
\end{tabular}

This work is licensed under a Creative Commons Attribution-Nomercial-ShareAlike 4.0 International License. Ciptaan disebarluaskan di bawah Lisensi Creative Commons Atribusi-BerbagiSerupa 4.0 Internasional. 


\begin{tabular}{lcccccc}
\hline \multicolumn{1}{c}{$\mathbf{R}$} & $\begin{array}{c}\mathbf{R} \\
\text { Square }\end{array}$ & Konstanta & $\begin{array}{c}\text { Koefisien } \\
\text { Regresi }\end{array}$ & Sig & $\boldsymbol{\alpha}$ \\
\hline Motivasi 0,859 & 0,739 & 10,461 & 0,886 & 0,000 & 0.01 \\
\hline Pengujian Signifikan & & & & \\
\hline
\end{tabular}

Keterangan: Variabel Kinerja

Sumber: data diolah 2021

Berdasarkan Tabel 3, nilai koefisien determinasi $\left(\mathrm{R}^{2}\right)$ sebesar 0.739 , artinya motivasi memberikan kontribusi sebesar 73,9\% terhadap kinerja karyawan PT Asian Tec Indonesia, sedangkan sisanya sebesar $26,1 \%$ disumbangkan faktor lain.

Persamaan regresi : $\mathrm{Y}=10,461+0,886\left(\mathrm{X}_{2}\right)$

Motivasi berpengaruh positif dan signifikan pada tingkat nyata $99 \%$ terhadap kinerja karyawan PT Asian Tec Indonesia. Koefisien motivasi sebesar 0,886, artinya jika ada peningkatan motivasi, maka kinerja karyawan PT Asian Tec Indonesia akan meningkat..

\section{Analisis regresi linear berganda}

Tabel 4: Pengaruh Kompensasi dan Motivasi Terhadap Kinerja Karyawan

\begin{tabular}{lcccccc}
\hline \multirow{2}{*}{ Variabel } & \multicolumn{6}{c}{ Parameter } \\
\cline { 2 - 7 } & Mult. R & $\begin{array}{c}\text { R } \\
\text { Square }\end{array}$ & Konstanta & $\begin{array}{c}\text { Koefisien } \\
\text { Regresi }\end{array}$ & Sig. & $\boldsymbol{\alpha}$ \\
\hline $\begin{array}{l}\text { Kompensasi } \\
\text { Motivasi }\end{array}$ & 0,867 & 0,751 & 10,037 & $\begin{array}{c}0,225 \\
0,677\end{array}$ & 0,004 & 0.014 \\
\hline
\end{tabular}

\begin{tabular}{l} 
Pengujian Signifikan \\
\hline F hitung $>$ F tabel $=40,790>3,354$
\end{tabular}

Keterangan: Variabel Kinerja

Sumber: data diolah 2021

Berdasarkan Tabel 4, nilai $\mathrm{F}$ hitung sebesar 40,790, artinya secara bersama-sama kompensasi dan motivasi berpengaruh signifikan pada tingkat nyata $99 \%$ terhadap kinerja karyawan PT Asian Tec Indonesia. Nilai koefisien determinasi $\left(\mathrm{R}^{2}\right)$ sebesar 0.751 , artinya kompensasi dan motivasi memberikan kontribusi sebesar 75,1\% kepada kinerja karyawan PT Asian Tec Indonesia, sedangkan sisanya sebesar 24,9\% disumbangkan faktor lain yang tidak dibahas dalam penelitian ini.

Persamaan regresi

$\mathrm{Y}=10,037+0,225\left(\mathrm{X}_{1}\right)+0,677\left(\mathrm{X}_{2}\right)$

Kompensasi dan motivasi berpengaruh positif dan signifikan terhadap kinerja karyawan PT Asian Tec Indonesia, pada tingkat nyata 99\%. Koefisien kompensasi sebesar 0,225, artinya jika ada peningkatan kompensasi, maka kinerja karyawan PT Asian Tec Indonesia akan meningkat dengan asumsi motivasi tidak berubah. Koefisien motivasi sebesar 0,677, artinya jika ada peningkatan motivasi, maka kinerja karyawan PT Asian Tec Indonesia akan meningkat, dengan asumsi kompensasi tidak berubah.

\section{Pembahasan}

This work is licensed under a Creative Commons Attribution-Nomercial-ShareAlike 4.0 International License. Ciptaan disebarluaskan di bawah Lisensi Creative Commons Atribusi-BerbagiSerupa 4.0 Internasional. 


\section{Pengaruh Kompensasi Terhadap Kinerja Karyawan}

Hasil penelitian menunjukan bahwa kompensasi mendukung peningkatan kinerja karyawan PT Asian Tec Indonesia. Hal ini menunjukkan bahwa gaji yang diberikan perusahaan setiap bulan dapat memenuhi kebutuhan keluarga, upah sesuai dengan ketentuan yang berlaku, insentif diberikan pada karyawan berprestasi dalam bentuk finansial, diberikan asuransi kesehatan kerja, mendapatkan BPJS hari tua, adanya antar jemput karyawan, dan pimpinan mendaptkan fasilitas mobis dinas. Hasil penelitian ini sejalan dengan penelitian yang dilakukan oleh Heriyanto, (2020), dan Syaifullah \& Prasetyo, (2018) yang menyatakan bahwa kompensasi berpengaruh signifikan terhadap kinerja karyawan, maka hipotesis pertama dapat diterima.

\section{Pengaruh Motivasi Terhadap Kinerja Karyawan}

Hasil penelitian menyatakan bahwa motivasi mendorong peningkatan kinerja karyawan PT Asian Tec Indonesia. Hal ini dikarenakan bahwa perusahaan memberikan penghargaan atas jasa karyawan dalam bentuk uang dan barang, kondisi kerja nyaman, lingkungan kerja cukup baik, semua fasilitas kerja disiapkan perusahaan, yang berprestasi mendapat reward, adanya pengakuan kerja yang diberikan pada karyawan, dan pekerjaan yang dilakukan karyawan menjadi motivasi sendiri. Hasil penelitian ini sejalan dengan hasil penelitian yang dilakukan Wijaya dan Andreani, (2015) dan Dewi, et al (2019) yang menyatakan bahwa motivasi berpengaruh signifikan terhadap kinerja karyawan, maka hipotesis kedua dapat diterima.

\section{Pengaruh Kompensasi Dan Motivasi Terhadap Kinerja Karyawan}

Berdasarkan hasil analisis diketahui bahwa kompensasi dan motivasi mendukung peningkatan kinerja karyawan PT Asian Tec Indonesia. Hasil penelitian ini sama dengan hasil penelitian yang dilakukan Asriani, et al, (2020), dan Gusmao, et, al (2018), yang menyatakan bahwa kompensasi dan motivasi berpengaruh terhadap kinerja karyawan, maka hipoteis ketiga dapat diterima.

\section{KESIMPULAN DAN SARAN}

\section{Kesimpulan}

Berdasarkan uraian hasil pembahasan maka dapat disimpulkan bahwa: 1). Kompensasi berpengaruh positif dan signifikan terhadap kinerja karyawan PT Asian Tec Indonesia Jakarta Utara. 2). Motivasi berpengaruh positif dan signifikan terhadap kinerja karyawan PT Asian Tec Indonesia Jakarta Utara. 3). Kompensasi dan motivasi secara bersama-sama berpengaruh positif dan signifikan terhadap kinerja karyawan PT Asian Tec Indonesia Jakarta Utara.

\section{Saran}

Berdasarkan hasil dari penarikan kesimpulan dan berdasarkan hasil penelitian yang telah dibahas, maka ada beberapa saran sebagai berikut: 1). Penelitian ini diharapkan dapat digunakan sebagai bahan pertimbangan mengenai pentingnya memberikan kompensasi untuk meningkatkan kinerja. Artinya perusahaan masih perlu meningkatkan jumlah kompensasi yang diberikan kepada karyawan, khsusunya pemberian bonus yang lebih menarik yang disesuaikan dengan pekerjaan karyawan, sehingga karyawan akan merasa lebih puas dalam bekerja dan dapat lebih termotivasi serta dapat meningkatkan kinerja karyawan. 2 2). Penelitian ini diharapkan dapat menambah pengetahuan bagi peneliti sendiri atas pemahaman ilmu yang telah diperoleh selama kuliah, terutama 
dalam hal-hal yang terkait dengan kompensasi, motivasi dan kinerja karyawan. 3). Penelitian ini diharapkan dapat membeikan kontribusi bagi pengembangan penelitian dan menjadi acuan bagi penelitian selanjutnya yang berkaitan dengan kompensasi, motivasi dan kinerja dengan bahasan yang lebih mendalam.

\section{DAFTAR PUSTAKA}

Afandi, P. 2018. Manajemen Sumber Daya Manusia (Teori, Konsep dan Indikator). Riau: Zanafa Publishing.

Asriani., Lorensa, Devia., Saputri, Pebrida dan Hidayati, Tetra. 2020. The Effect of Compensation and Motivation to Employee Performance. International Journal of Economics, Business and Accounting Research (IJEBAR). Vol. 4, Issue-1, 2020. EISSN: 2614-1280, P-ISSN: 2622-4771. Hal. 166-172.

Dewi, Puspa., Fikri, Khusnul dan Fitrio, Tomy. 2019. The Effect of Work Motivation on Employees' Performance Mediated by Job Satisfaction at PT. Bank Rakyat Indonesia TBK Rengat Branch Office. International Journal of Scientific Research and Management (IJSRM) Volume 07 Issue 09 Pages EM-2019-1344-1358, 2019, ISSN (e): 2321-3418

Edison., Anwar dan Komariyah. 2016. Manajemen Sumber Daya Manusia. Edisi Pertama. Bandung : Alfabeta.

Flippo, Edwin B. 2013. Personel Management (Manajemen Personalia). Edisi VII Jilid II, Terjemahan Alponso S. Jakarta: Erlangga.

Gusmao, Juliao Freitas dan Riana, Gede. 2018. Pengaruh Kompensasi Terhadap Motivasi dan Kinerja Pegawai Administrasi Di Dinas Pendidikan Distrik Baucau Timor Leste. Jurnal Buletin Studi Ekonomi. Vol. 23 No. 1, Februari 2018. Hal. 138-153

Handoko, T. Hani. 2014. Manajemen Personalia dan Sumber Daya Manusia. Yogyakarta: BPFE.

Hariandja, Marihot Tua Efendi. 2007. Manajemen Sumber Daya Manusia: Pengadaan, Pengembangan, Pengkompensasian, dan Peningkatan Produktivitas Pegawai. Jakarta: Grasindo

Hasibuan, Malayu S.P. 2017. Manajemen Sumber Daya Manusia. Jakarta: PT. Bumi Aksara. Heriyanto, Agustinus Yanuar Budhi. 2020. Pengaruh Kompensasi dan Motivasi Terhadap Kinerja Karyawan PT Indoraya Internasional. Jurnal Manajemen. Vol. 12 (1) 2020, 99-98. pISSN: 0285-6911 -e-2528-1518.

Mangkunegara, Anwar Prabu. 2017. Manajemen Sumber Daya Manusia Perusahaan, Cetakan Kesepuluh, Bandung: PT. Remaja Rosdakarya.

Marwansyah. 2016. Manajemen Sumber Daya Manusia. Edisi Dua. Cetakan Keempat. Bandung: CV. Alfabeta.

Nawawi. 2011. Manajemen Sumber Daya Manusia Untuk Bisnis yang Kompetitif, Yogyakarta: Gajah Mada University Press.

Prawirosentono, Suryadi. 2008. Kinerja. Bandung: Alfabeta.

Rivai, Veithzal, 2014. Manajemen Sumber Daya Manusia untuk Perusahaan : dari Teori Ke Praktik, Edisi Pertama, Depok: Penerbit PT. Raja Grafindo Persada.

Simamora, Henry. 2010. Manajemen Sumber Daya Manusia, Edisi ke-1, Cetakan Kedua, Yogyakarta: Bagian Penerbitan STIE YKPN

Sugiyono. 2017. Statikstika Untuk Penelitian. Bandung: Alfabeta.

Sunyoto, Danang. 2012. Manajemen Sumber Daya Manusia. Jakarta: PT Buku Seru.

Sutrisno, Edy 2016, Manajemen Sumber Daya Manusia, Cetakan Kedelapan, Jakarta: Prenamedia Group. 
Syaifullah, As'ad dan Prasetyo, Iwan Adhi. 2018. Pengaruh Kompensasi dan Motivasi Terhadap Kinerja Karyawan Pt. Prima Bumi Pakuwon. Jurnal Inovasi, 14 (1) 2018, 1 7. ISSN Print: 0216-7786- ISSN Online: 2528-1097.

Terry. R. George. 2005. Dasar-Dasar Manajemen. Cetakan Kesembilan. Jakarta: PT.Bumi Aksara.

Umar, Husein. 2007. Riset Sumber Daya Manusia Dalam Organisasi. Edisi Revisi. Jakarta: PT.Gramedia Pustaka Utama.

Uno, Hamzah B. 2011. Teori Motivasi dan Pengukurannya. Jakarta: PT Bumi Aksara.

Wibowo. 2016. Manajemen Kinerja. Edisi Keempat. Jakarta: Rajawali Pers.

Wijaya, Tanto dan Andreani, Fransisca. 2015. Pengaruh Motivasi dan Kompensasi Terhadap Kinerja Karyawan Pada PT Sinar Jaya Abadi Bersama. Jurnal Agora Vol. 3, No. 2 (2015), hal. 37-45. 